\title{
Visualising the Cardiovascular System of Embryos of Biomedical Model Organisms with High Resolution Episcopic Microscopy (HREM)
}

\author{
Wolfgang J. Weninger ${ }^{1, *}$, Barbara Maurer-Gesek ${ }^{1}$, Lukas F. Reissig ${ }^{1}$, Fabrice Prin ${ }^{2}$, \\ Robert Wilson ${ }^{2}$, Antonella Galli ${ }^{3}$, David J. Adams ${ }^{3}$, Jacqueline K. White ${ }^{3}$, Timothy J. Mohun ${ }^{2}$ \\ and Stefan H. Geyer ${ }^{1}$ \\ 1 Division of Anatomy \& MIC, Medical University of Vienna, 1090 Vienna, Austria; \\ barbara.maurer-gesek@meduniwien.ac.at (B.M.-G.); lukas.reissig@meduniwien.ac.at (L.F.R.); \\ stefan.geyer@meduniwien.ac.at (S.H.G.) \\ 2 The Francis Crick Institute, London NW1 1AT, UK; Fabrice.Prin@crick.ac.uk (F.P.); rwilson@ebi.ac.uk (R.W.); \\ tim.mohun@crick.ac.uk (T.J.M.) \\ 3 Wellcome Trust Sanger Institute, Cambridge CB10 1SA, UK; antonella.galli@abcam.com (A.G.); \\ da1@sanger.ac.uk (D.J.A.); jacqui.white@jax.org (J.K.W.) \\ * Correspondence: wolfgang.weninger@meduniwien.ac.at; Tel.: +43-1-40160-37560
}

Received: 23 November 2018; Accepted: 11 December 2018; Published: 15 December 2018

\begin{abstract}
The article will briefly introduce the high-resolution episcopic microscopy (HREM) technique and will focus on its potential for researching cardiovascular development and remodelling in embryos of biomedical model organisms. It will demonstrate the capacity of HREM for analysing the cardiovascular system of normally developed and genetically or experimentally malformed zebrafish, frog, chick and mouse embryos in the context of the whole specimen and will exemplarily show the possibilities HREM offers for comprehensive visualisation of the vasculature of adult human skin. Finally, it will provide examples of the successful application of HREM for identifying cardiovascular malformations in genetically altered mouse embryos produced in the deciphering the mechanisms of developmental disorders (DMDD) program.
\end{abstract}

Keywords: imaging; high resolution episcopic microscopy; HREM; embryo; phenotyping; episcopic; 3D; mouse; chick; developmental biology

\section{Introduction}

During gastrulation, embryos form a simple tubular heart. It pumps blood into a similarly simple and symmetrically arranged arterial system. During the following embryo periods and, to smaller extent even peri- and postnatally, both the heart and vascular system undergo extensive remodelling, which transforms them into complexly shaped and asymmetrically arranged organs.

The remodelling processes are driven and orchestrated by genetic and biomechanical factors, which interact in a strict temporal and spatial corset. Errors result in moderate to severe cardiovascular disorders but can potentially trigger abnormal formation and growth of all organ systems throughout the body.

Due to the central role the cardiovascular system plays in the embryonic, foetal and postnatal life, the genetic and biomechanical factors regulating normal cardiovascular development and the mechanisms underlying its pathologies are the focus of biomedical research [1-7]. For such research, a large number of tools for labelling active genes and gene products and for modifying or physically challenging their interplay during critical steps of development and growth were created and 
successfully established. Yet, all these tools produce effects that need to be properly visualised. Hence the existence of decent visualisation methods is at the core of cardiovascular research.

In particular visualisation and descriptive analysis of in situ distribution of gene expression information and of subtle morphologic defects caused by gene deletions, hemodynamic experiments or by alteration of the physical or chemical environment in embryos of model organisms remains a major challenge. The traditional imaging approach, which is careful analysis of series of two-dimensional (2D) histologic sections, is highly inefficient. This chiefly for two reasons: Firstly, embryos and their cardiovascular systems are of a complex three-dimensional (3D) arrangement, making it virtually impossible to comprehend the exact topology on the basis of two-dimensional (2D) information. Secondly, the production and examination of histologic sections is slow and time-consuming.

For coping with the drawbacks of conventional histological sections and section-based imaging methods [8-10], the last few decades have seen the development of large numbers of innovative $3 \mathrm{D}$ imaging technologies covering the meso- and microscopic range. The most promising are micro computed tomography $(\mu \mathrm{CT})$ —even termed as virtual histology [11-19], micro-magnetic resonance imaging ( $\mu$ MRI) [20-30], optical projection tomography (OPT) [31-37], optical coherence tomography (OCT) [38-41], photoacoustic tomography (PAT) [40,42], serial block face microscopy [43,44], ultrasound microscopy [45-49], Episcopic 3D microscopy (Epi3D) [50], Episcopic Fluorescence Image Capturing (EFIC) [51,52] and High Resolution Episcopic Microscopy (HREM) [53-56]. A similar, episcopic approach is used for serial block-face electron microscopy (SBFSEM), which offers ultrastructural 3D information [57-59].

This paper aims to focus on one of these techniques, HREM, and its potential for visualising the cardiovascular system of normal and genetically altered embryos of biomedical models. In addition, it will briefly introduce the ability of using HREM for visualising the vascular system in biopsy material stemming from human tissue.

\section{What Is High-Resolution Episcopic Microscopy (HREM)}

High resolution episcopic microscopy is a technique for visualising the morphology of materials embedded in eosin stained methacrylate resin JB4. While cutting through the sample, series of inherently aligned digital images are created from subsequently exposed block surfaces. These images are virtually stacked and converted to volume data of high resolution and quality.

HREM volume data fit excellently for in situ visualisation, volumetry, planimetry and mathematical analysis of the components of the cardiovascular system of genetically normal, genetically engineered and physically and chemically challenged embryos of all popular model organisms. In selected cases HREM also permits 3D visualisation of gene expression and gene product patterns and the characterisation of cell distributions in their natural context. Hence, it was already successfully employed in several projects studying normal embryogenesis [60-65] and the role genes play in selected human diseases [66-70]. But, most importantly, HREM was introduced for the deciphering the mechanisms of the developmental disorders program (DMDD, www.dmdd.org.uk) as a method for screening the morphological phenotype of mouse embryos harvested at embryonic day (E) 14.5. In DMDD nearly 700 mouse embryos, stemming from 87 knock out lines, which produce embryonically lethal offspring were screened and their annotated data are provided on a freely accessible webpage [71-74].

The workflow of HREM data creation is simple and will be briefly outlined in the following chapters.

\subsection{Sample Preparation}

Sample preparation involves fixation and dehydration. A broad spectrum of fixation solutions and dehydration in series of increasing ethanols or methanols is suitable. Yet, for gaining excellent data quality, sample processing has to be slightly adapted to meet the specific requirements of tissues, organisms and developmental stages [53,75]. Also, if possible, perfusion with physiologic solutions 
for washing out the blood of cardiac chambers and/or blood vessels should be performed prior to embedding.

\subsubsection{Fixation}

Most commonly, fresh material and loose neonatal and adult tissues are fixed in 4\% PFA/PBS or Bouin's solution for $24 \mathrm{~h}$ to several days, depending on sample size. Fixation time lasts for at least 1 day and does not exceed several weeks. Adult tissues, especially biopsy material harvested from the human skin and heart, are fixed in 2\% PFA/PBS containing $4 \%$ carbolic acid and the samples are kept in this solution for at least one week and a maximum of twelve months [76]. If whole mount staining with dye reactions, e.g., the NBT/BCIP detection system was conducted prior to dehydration and resin embedding, the samples must be immersed in fixation solution before and after the staining procedure.

\subsubsection{Dehydration}

After fixation, the samples are dehydrated in a series of methanols or ethanols with increasing concentrations $(50 \%, 70 \%, 80 \%, 90 \%, 96 \%)$. Additional dehydration steps might be added for minimizing shrinkage artefacts. Depending on the volume of the specimens, they are kept from approximately $20 \mathrm{~min}$ (early zebrafish embryos) to up to $3 \mathrm{~h}$ (dense skin biopsy material) in each alcohol. Tissue contrast in large tissue samples profits from adding eosin to the higher alcohols $[75,76]$.

\subsubsection{Infiltration}

After dehydration, the samples are infiltrated with and embedded in JB4-resin (Polysciences) containing eosin $(0.4 \mathrm{~g} / 100 \mathrm{~mL})$ or alternatively eosin and acridine orange $(0.275 \mathrm{~g}$ eosin $/ 100 \mathrm{~mL}$ and $0.055 \mathrm{~g}$ acridine orange $/ 100 \mathrm{~mL}$ ). Except for stirring eosin/arcridine orange into the solutions, the infiltration and embedding solutions are prepared following the instructions of the Polysciences embedding kit. Infiltration times depend on specimen size and range between 3-4 h (small zebrafish embryos) and $48 \mathrm{~h}$ (4 mm skin biopsy material).

\subsubsection{Embedding}

Following infiltration, the specimens are placed in embedding moulds, filled with liquid embedding solution, composed of JB4-resin (Polysciences), which contains eosin $(0.4 \mathrm{~g} / 100 \mathrm{~mL})$ or alternatively eosin and acridine orange $(0.275 \mathrm{~g}$ eosin $/ 100 \mathrm{~mL}$ and $0.055 \mathrm{~g}$ acridine orange $/ 100 \mathrm{~mL})$. The typical size of commercial embedding moulds ranges between $6 \times 8 \times 5 \mathrm{~mm}^{3}$ and $8 \times 10 \times 16 \mathrm{~mm}^{3}$.

After setting the block holders on top of the moulds, the moulds with block holders are sealed airproof with paraplast or by covering the surface with mineral oil to support hardening of the resin. Placing the airproof covered moulds in the fridge for approximately two days reduces the likeliness of the occurrence of bubbles or cavities inside the resin.

After hardening is completed, the polymerised blocks are either baked at $70-90{ }^{\circ} \mathrm{C}$ for 1 to 2 days for accelerated hardening and darkening of the resin, or simply stored for at least a week at room temperature. Blocks are then transferred to the room in which they are sectioned and stored for a few days before they are mounted on the microtome of the HREM apparatus. Storage for months is possible, although blocks older than one year tend to be brittle and break more easily during sectioning.

\subsection{HREM Data Generation}

The resin blocks are mounted in an HREM apparatus and sectioned, while series of digital images showing freshly cut block surfaces are captured. Sectioning is performed in an air-conditioned room at $18^{\circ}$ to $20^{\circ}$ Celsius, as high temperatures and humidity soften the block. The specifications of the components comprising a HREM-setup and the exact workflow during sectioning have been described in detail previously $[56,77]$. 


\subsubsection{HREM Apparatus}

An HREM apparatus essentially comprises a microtome or device for sectioning resin blocks in 1 to $5 \mu \mathrm{m}$ steps. The sectioning device is equipped with a photo-position, at which the block containing the sample reproducibly stops after each cut. A fluorescence optics is aligned with the photo-position. Its optical axis comprises a GFP or YFP filter cube. If specimens are specifically stained with bluish stains, GFP or YFP and Texas Red filter cubes are subsequently placed in the optical axis. On the phototube of the optics sits a digital camera, which is connected to a PC operating a data generation software that orchestrates cutting, image capturing and image storage. A device for focusing and for adjusting the field of view completes the set up (Figure 1).

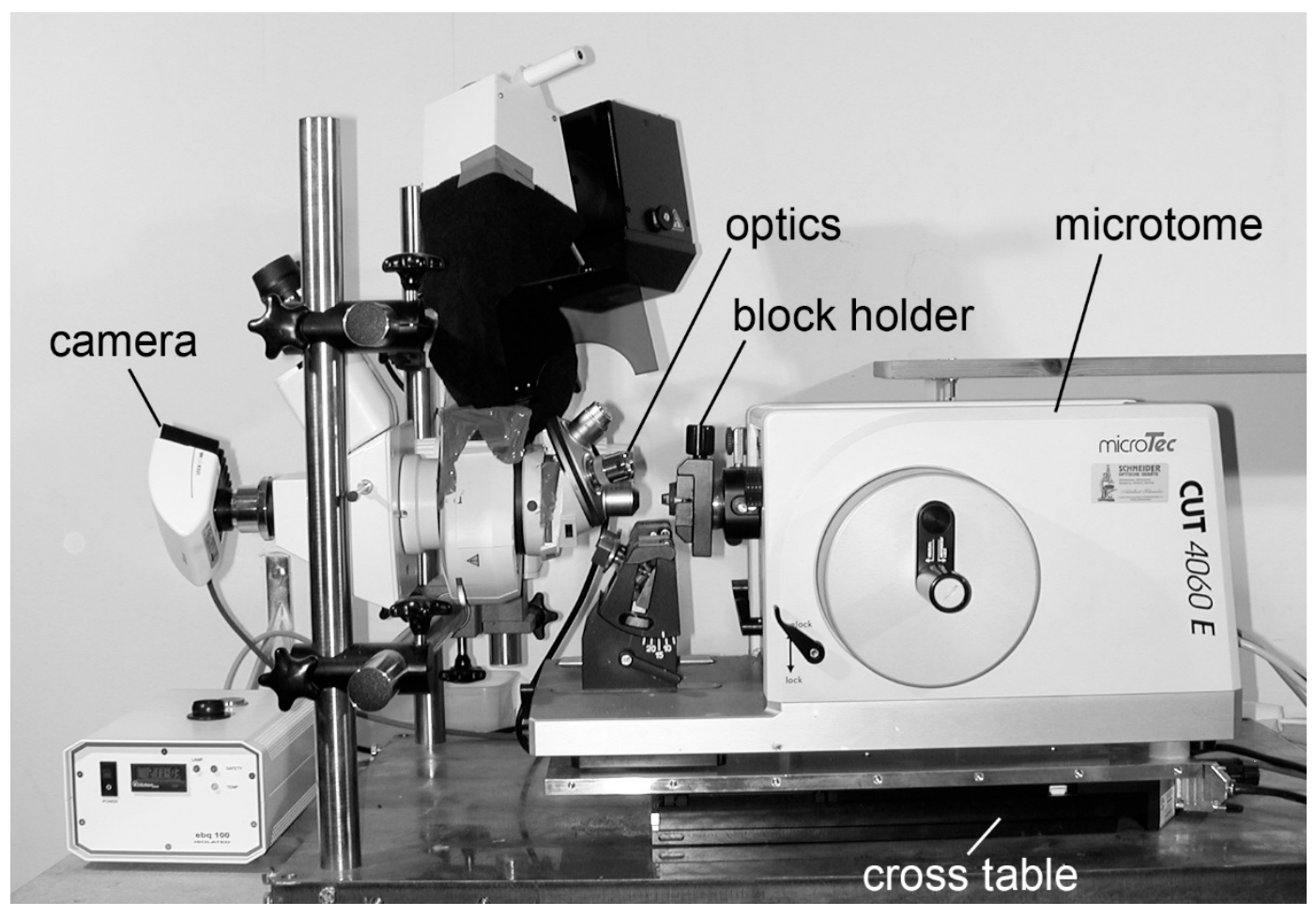

Figure 1. HREM apparatus.

Various prototypes of HREM apparatuses are in use [53,78]. But recently a ready to use setup has also been made commercially available by Indigo Scientific Ltd. (Baldock, UK) (OHREM, http:/ /www.indigo-scientific.co.uk/).

In routine projects, HREM apparatuses produce volume data comprised of 3000-4000 inherently aligned section images in about $8 \mathrm{~h}$. The voxel dimensions of the created volume data range between $2 \times 2 \times 2 \mu \mathrm{m}^{3}$ and $5 \times 5 \times 5 \mu \mathrm{m}^{3}$, depending on the desired field of view. Larger and smaller dimensions are possible but require customised set ups and skilled operators.

\subsubsection{Data Processing}

HREM data are either contrast enhanced by routines and archived, or directly loaded into 3D visualisation software, such as Amira ${ }^{\circledR}$ (versions 5-6, ThermoFisher Scientific, Merignac, France), Osirix ${ }^{\circledR}$ (www.osirix-viewer.com, versions 6-8, Pixmeo SARL, Bernex, Switzerland) or Imaris ${ }^{\circledR}$ (version 9, Bitplane AG, Zürich, Switzerland). If section thickness does not correspond with the pixel size of the digital images, scaling of the single images to match the section thickness by using Photoshop $^{\circledR}$ (version 11, Adobe Systems, San Jose, CA, USA) or IrfanView (irfanview.com, version 4, Irfan Škiljan, Wiener Neustadt, Austria) routines is of advantage for later metric analysis. 


\subsubsection{Data Visualisation}

HREM data are ideal for immediate volume rendering and thus 3D models with exceptional resolution can be generated within seconds. The high contrasts of HREM data enable fully automated segmentation of body surfaces and subsequent surface rendering. 3D surface modelling of embryo organs, such as the central nervous system, lungs, liver pancreas, endocrine glands and others requires semi-automatic segmentation by, e.g., using region growing algorithms and interactive demarcation of the organ borders from adjacent structures. 3D surface modelling of structures such as blood vessels, nerves and ganglia requires manual tracing in most cases.

Rapid visualization of specifically labelled structures (e.g., LacZ or NBT/BCIP stained gene products) is possible by using multi-channel imaging. Two images are captured from each block surface. One with a GFP or YFP and one with a Texas Red filter set. Overall embryo morphology is visualised by using volume rendering in the GFP/YFP image set. Specifically stained structures are visualised as surface models after automated threshold segmentation in the image set captured with the Texas Red filter (Leica-Microsystems, Wetzlar, Germany).

\section{Examples}

Since its first publication in 2006, HREM has been used to analyse a variety of embryonic and adult samples. The following section provides examples of the successful use of HREM for analysing cardiovascular components.

Use of all animals was in accordance with UK Home Office regulations, the UK Animals (Scientific Procedures) Act of 1986 and approved by the Wellcome Trust Sanger Institute's Animal Welfare and Ethical Review Body.

\subsection{Skin Vasculature}

The dermal layer of the skin harbours a highly complex system of blood vessels. They guarantee smooth supply of nutrients, oxygen and endocrine signals to all cells in all skin layers and, at the same time aid thermoregulation of the entire body.

In a few anatomical studies, HREM proved to be highly useful for analysing the topology and architecture of the dermal arteries in various regions of the human skin $[76,79,80]$. Yet it was also successful in visualising neovascularisation in wound healing models [81-83] (Figure 2). In this context we like to emphasise that the dense tissues of adult humans and animals prevent automatic detection of blood vessels, where blood vessel segmentation has to be performed by manual tracing. 

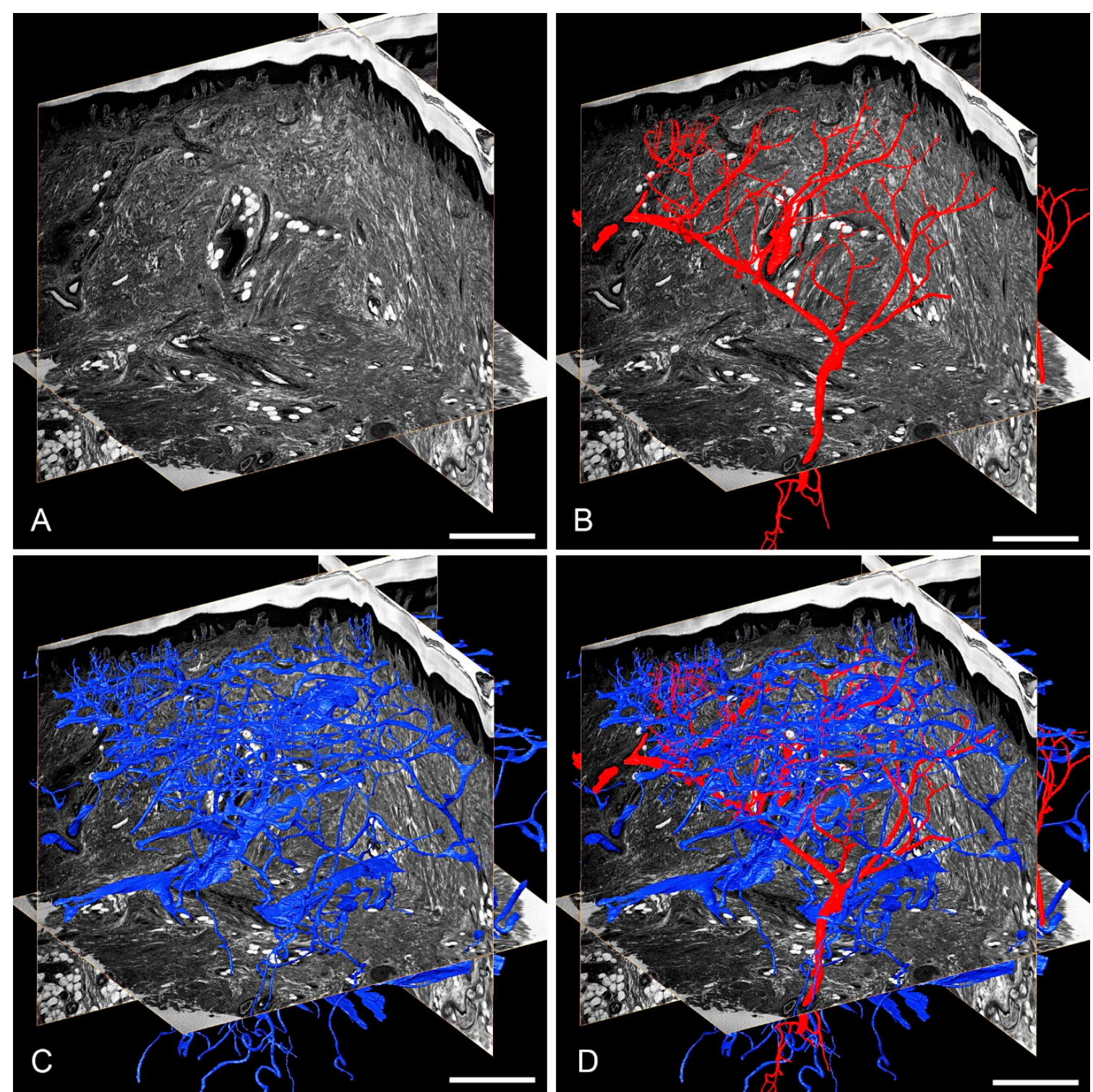

Figure 2. Thick skin of human thumb pad. Virtual sections through HREM data (A) together with surface models of dermal arteries (B), dermal veins (C) and both (D). Scalebars: $500 \mu \mathrm{m}$.

\subsection{Biomedical Model Organisms}

\subsubsection{Zebrafish and Frog Embryos}

HREM has been successfully used to image the heart of early zebrafish and frog embryos [53]. Due to the small sample size, also whole mount in situ hybridisation of mlc2a products could be used and allowed automated detection of heart cells. The insensitivity of HREM for artefacts caused by yolk and the high-resolution of the produced volume data allowed 3D imaging of the heart tube of 24-28 hpf zebrafish embryos in the context of the entire embryo sitting on the yolk sac. These data are excellently fitted for metric analysis of the cardiac axis of normal and mutated embryos in respect to the axis of the neural tube and other embryonic structures (Figure 3). 

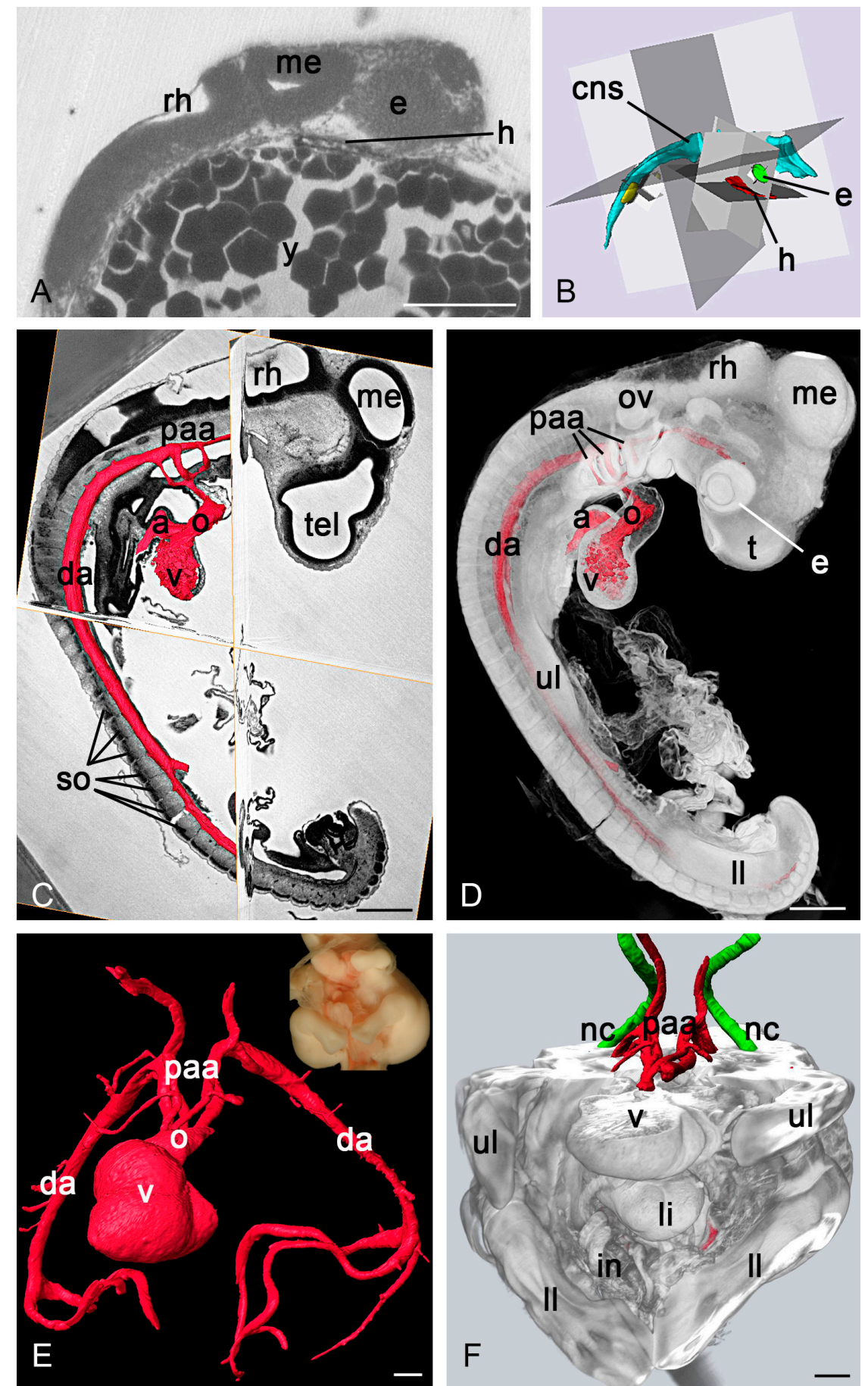

Figure 3. HREM for analysing the cardiovascular system of biomedical models. (A) Sagittal section through the head of a zebrafish embryo, $48 \mathrm{~h}$ after conception. (B) Surface models of the cranial parts of the central nerve system (cns), eye (e) and heart (h) with mathematically calculated and displayed planes through their main axes. (C,D) Surface models of the heart and arteries (red) of a chick embryo of stage 18 according to Hamburger Hamilton $(\mathrm{HH})$ together with virtual resections through HREM data (C) and in the context of a semitransparent volume model of the embryo surface (D) respectively. (E,F) HH 34 chick embryo with cephalothoracopagus malformation. Surface models show a single heart and pharyngeal arch artery system (red) feeding the descending aorta of each twin (E). Additional surface models of the notochords (nc, green) in an opaque volume model of the surface with virtually excluded cranial parts from anterior (F). a, atrium; da, dorsal aorta; e, eye; in, intestine; li, liver; ll, lower limb; me, mesencephalon; nc, notochord; o, outflow tract; ov, otic vesicle; paa, pharyngeal arch arteries; rh, rhombencephalon; so, somite; $t$, telencephalon; ul, upper limb; v, ventricle. Scalebars: $100 \mu \mathrm{m}(\mathbf{A})$, $500 \mu \mathrm{m}(\mathbf{C}-\mathbf{F})$. 


\subsubsection{Chick Embryos}

HREM was successfully applied for visualising the heart and great blood vessels of normally developed and biomechanically challenged early to late chick embryos, from developmental stage 5 to 35 according to the staging system suggested by Hamburger and Hamilton [84] (Figure 3). The data enabled precise descriptions of pharyngeal arch artery remodelling and, in early embryos $3 \mathrm{D}$ visualisation of the distribution of specifically labelled Tbx5 and $n k x 2.5$ products in the myocardium. In addition, HREM was successfully applied for visualising cardiovascular morphology of experimentally produced mutants $[85,86]$ and for metric descriptions of the dimensions and angles of the great arteries $[60,86]$.

In early embryos HREM permits visualisation of the cardiovascular system in the context of the whole embryo. Embryos older than HH28 must be parted for HREM imaging and only the thoraces or isolated hearts can be processed.

\subsubsection{Mouse Embryos}

HREM proved to work excellently with normal and genetically engineered early to late mouse embryos. It was successfully used visualising the single steps during cardiovascular remodelling and for metric analysis of the dimensions of the great intrathoracic arteries and the lengths of vessel segments $[60,62,63,87-89]$. HREM also was applied for visualising structural abnormalities in various knock out lines serving as models for human diseases [68,90-92].

An important application of HREM was its use in the scope of the Deciphering the Mechanisms of Developmental Disorders (DMDD) program (https://dmdd.org.uk). HREM data of nearly 700 embryos of 87 knock out lines producing embryonically lethal offspring have been produced and thoroughly analysed in this program. Due to the unmatched spatial resolution and image quality of HREM and the availability of newly created reference data precisely defining normal cardiovascular morphology in the substages of E14.5 [93] vascular variations, large and small heart defects, but also entirely new and potentially life-threatening cardiovascular abnormalities were diagnosed and annotated [72] (Figure 4). 


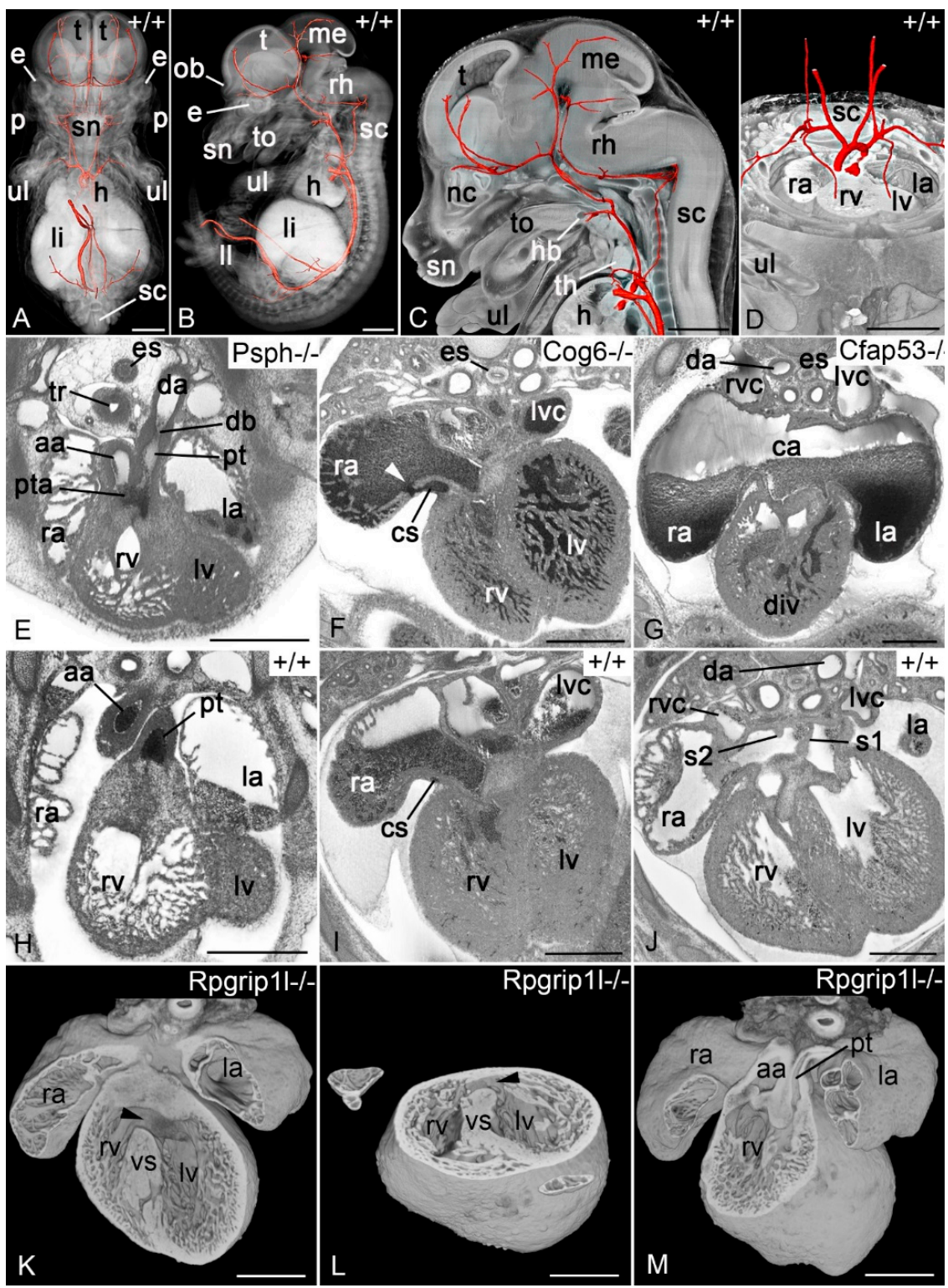

Figure 4. Cardiovascular features in HREM data of mouse embryos harvested at E14.5. (A,B) Surface rendered models of the arteries (red) together with a semi-transparent volume model from frontal (A) and lateral (B). (C) Surface rendered models of the head arteries (red) together with a sagittally sectioned volume model of the upper body half of an embryo. (D) Surface rendered models of the great intrathoracal arteries in an axially sectioned volume model. For details regarding artery topology see [87]. (E-J) Axial HREM sections, showing examples of cardiovascular malformations diagnosed in mutants produced in the DMDD program (E-G) and comparable sections through controls (H-J). Provided examples show persistent truncus arteriosus (pta) in a Psph mutant (E), additional opening of the coronary sinus (cs) into the right atrium (arrowhead) in a Cog6 mutant (F), and a complex malformation including common atrium (ca), double inlet left ventricle (div) and right sided descending aorta (da) in a Cfap53 mutant (g). (K-M) Volume rendered models of isolated hearts displaying heart malformations of a Rpgrip mutant. Perimembranous ventricular septal defect (pVSD) (K), muscular ventricular septal defect (mVSD) (L), double outlet right ventricle (DORV) (M). aa, ascending aorta; db, ductus arteriosus; e, eye; es, espophagus; h, heart; hb, hyoid bone; la, left atrial appendix; ll, lower limb; li, liver; lv, left ventricle; lvc, left vena cava superior; me, mesencephalon; nc, nasal cavity; ob, olfactory bulb; p, pinna; ra, right atrial appendix; rh, rhombencephalon; rv, right ventricle; rvc, right vena cava superior; sc, spinal chord; sn, snout; s1, septum primum; s2, septum secundum; $t$, telencephalon; th, thymus; to, tongue; tr, trachea; ul, upper limb; vs, ventricular septum. Scalebars $1 \mathrm{~mm}(\mathbf{A}-\mathbf{D}), 500 \mu \mathrm{m}(\mathbf{E}-\mathbf{M})$. 
Author Contributions: W.J.W. and S.H.G. created data, assembled figures and wrote the article. B.M.-G. and L.F.R. created and processed data and contributed to preparing figures. F.P. and R.W. contributed to HREM data processing, data mining and creation of figures. A.G., D.J.A. and J.K.W. identified lethal mouse lines and provided and processed their embryos. T.J.M. produced heart models and contributed to finalization of the manuscript.

Funding: Deciphering the mechanims of developmental disorders (DMDD) was supported by the Wellcome Trust [100160], [FC001157], [FC001117]; Cancer Research UK [FC001157], [FC001117]; and the UK Medical Research Council [FC001157], [FC001117].

Acknowledgments: The authors thank Luciano da F. Costa (Sao Carlos Institute of Physics, University of Sao Paulo) for mathematic analysis of zebrafish embryos.

Conflicts of Interest: The authors declare no conflict of interest.

\section{References}

1. Olson, E.N. A decade of discoveries in cardiac biology. Nat. Med. 2004, 10, 467-474. [CrossRef]

2. Srivastava, D. Making or breaking the heart: from lineage determination to morphogenesis. Cell 2006, 126, 1037-1048. [CrossRef] [PubMed]

3. Pierpont, M.E.; Basson, C.T.; Benson, D.W., Jr.; Gelb, B.D.; Giglia, T.M.; Goldmuntz, E.; McGee, G.; Sable, C.A.; Srivastava, D.; Webb, C.L. Genetic basis for congenital heart defects: Current knowledge: A scientific statement from the American Heart Association Congenital Cardiac Defects Committee, Council on Cardiovascular Disease in the Young: Endorsed by the American Academy of Pediatrics. Circulation 2007, 115, 3015-3038. [CrossRef] [PubMed]

4. Andelfinger, G. Genetic factors in congenital heart malformation. Clin. Genet. 2008, 73, 516-527. [CrossRef] [PubMed]

5. Dees, E.; Baldwin, H.S. Making a heart: Advances in understanding the mechanisms of cardiac development. Curr. Opin. Pediatr. 2016, 28, 584-589. [CrossRef] [PubMed]

6. Ivanovitch, K.; Esteban, I.; Torres, M. Growth and Morphogenesis during Early Heart Development in Amniotes. J. Cardiovasc. Dev. Dis. 2017, 4. [CrossRef] [PubMed]

7. Zaidi, S.; Brueckner, M. Genetics and Genomics of Congenital Heart Disease. Circ. Res. 2017, 120, $923-940$. [CrossRef]

8. Weninger, W.J.; Streicher, J.; Müller, G.B. 3-dimensional reconstruction of histological serial sections using a computer. Wien. Klin. Wochenschr. 1996, 108, 515-520.

9. Streicher, J.; Weninger, W.J.; Müller, G.B. External marker-based automatic congruencing: A new method of 3D reconstruction from serial sections. Anat. Rec. 1997, 248, 583-602. [CrossRef]

10. Streicher, J.; Donat, M.A.; Strauss, B.; Spörle, R.; Schughart, K.; Müller, G.B. Computer-based three-dimensional visualization of developmental gene expression. Nat. Genet. 2000, 25, 147-152. [CrossRef]

11. Metscher, B. MicroCT for comparative morphology: Simple staining methods allow high-contrast 3D imaging of diverse non-mineralized animal tissues. BMC Physiol. 2009, 9, 11-24. [CrossRef] [PubMed]

12. Metscher, B.D. MicroCT for developmental biology: A versatile tool for high-contrast 3D imaging at histological resolutions. Dev. Dyn. 2009, 238, 632-640. [CrossRef] [PubMed]

13. Metscher, B.D.; Müller, G.B. MicroCT for molecular imaging: Quantitative visualization of complete three-dimensional distributions of gene products in embryonic limbs. Dev. Dyn. 2011, 240, 2301-2308. [CrossRef] [PubMed]

14. Gignac, P.M.; Kley, N.J.; Clarke, J.A.; Colbert, M.W.; Morhardt, A.C.; Cerio, D.; Cost, I.N.; Cox, P.G.; Daza, J.D.; Early, C.M.; et al. Diffusible iodine-based contrast-enhanced computed tomography (diceCT): An emerging tool for rapid, high-resolution, 3-D imaging of metazoan soft tissues. J. Anat. 2016, 228, 889-909. [CrossRef] [PubMed]

15. Degenhardt, K.; Wright, A.C.; Horng, D.; Padmanabhan, A.; Epstein, J.A. Rapid 3D phenotyping of cardiovascular development in mouse embryos by micro-CT with iodine staining. Circ. Cardiovasc. Imaging 2010, 3, 314-322. [CrossRef] [PubMed]

16. Wong, M.D.; Dorr, A.E.; Walls, J.R.; Lerch, J.P.; Henkelman, R.M. A novel 3D mouse embryo atlas based on micro-CT. Development 2012, 139, 3248-3256. [CrossRef] [PubMed]

17. Johnson, J.T.; Hansen, M.S.; Wu, I.; Healy, L.J.; Johnson, C.R.; Jones, G.M.; Capecchi, M.R.; Keller, C. Virtual histology of transgenic mouse embryos for high-throughput phenotyping. PLoS Genet. 2006, 2, e61. [CrossRef] 
18. Hsu, C.-W.; Wong, L.; Rasmussen, T.L.; Kalaga, S.; McElwee, M.L.; Keith, L.C.; Bohat, R.; Seavitt, J.R.; Beaudet, A.L.; Dickinson, M.E. Three-dimensional microCT imaging of mouse development from early post-implantation to early postnatal stages. Dev. Biol. 2016, 419, 229-236. [CrossRef]

19. Núñez, J.A.; Goring, A.; Hesse, E.; Thurner, P.J.; Schneider, P.; Clarkin, C.E. Simultaneous visualisation of calcified bone microstructure and intracortical vasculature using synchrotron X-ray phase contrast-enhanced tomography. Sci. Rep. 2017, 7, 13289. [CrossRef]

20. Cleary, J.O.; Modat, M.; Norris, F.C.; Price, A.N.; Jayakody, S.A.; Martinez-Barbera, J.P.; Greene, N.D.E.; Hawkes, D.J.; Ordidge, R.J.; Scambler, P.J.; et al. Magnetic resonance virtual histology for embryos: 3D atlases for automated high-throughput phenotyping. Neuroimage 2011, 54, 769-778. [CrossRef]

21. Zamyadi, M.; Baghdadi, L.; Lerch, J.P.; Bhattacharya, S.; Schneider, J.E.; Henkelman, R.M.; Sled, J.G. Mouse embryonic phenotyping by morphometric analysis of MR images. Physiol. Genet. 2010, 42A, 89-95. [CrossRef] [PubMed]

22. Cleary, J.O.; Price, A.N.; Thomas, D.L.; Scambler, P.J.; Kyriakopoulou, V.; McCue, K.; Schneider, J.E.; Ordidge, R.J.; Lythgoe, M.F. Cardiac phenotyping in ex vivo murine embryos using microMRI. NMR Biomed. 2009, 22, 857-866. [CrossRef] [PubMed]

23. Berrios-Otero, C.A.; Wadghiri, Y.Z.; Nieman, B.J.; Joyner, A.L.; Turnbull, D.H. Three-dimensional micro-MRI analysis of cerebral artery development in mouse embryos. Magn. Reson. Med. 2009, 62, 1431-1439. [CrossRef] [PubMed]

24. Petiet, A.E.; Kaufman, M.H.; Goddeeris, M.M.; Brandenburg, J.; Elmore, S.A.; Johnson, G.A. High-resolution magnetic resonance histology of the embryonic and neonatal mouse: A $4 \mathrm{D}$ atlas and morphologic database. Proc. Natl. Acad. Sci. USA 2008, 105, 12331-12336. [CrossRef] [PubMed]

25. Schneider, J.E.; Bose, J.; Bamforth, S.D.; Gruber, A.D.; Broadbent, C.; Clarke, K.; Neubauer, S.; Lengeling, A.; Bhattacharya, S. Identification of cardiac malformations in mice lacking Ptdsr using a novel high-throughput magnetic resonance imaging technique. BMC Dev. Biol. 2004, 4, 16-27. [CrossRef]

26. Schneider, J.E.; Bhattacharya, S. Making the mouse embryo transparent: Identifying developmental malformations using magnetic resonance imaging. Birth Defects Res. 2004, 72, 241-249. [CrossRef] [PubMed]

27. Schneider, J.E.; Bamforth, S.D.; Farthing, C.R.; Clarke, K.; Neubauer, S.; Bhattacharya, S. Rapid identification and $3 \mathrm{D}$ reconstruction of complex cardiac malformations in transgenic mouse embryos using fast gradient echo sequence magnetic resonance imaging. J. Mol. Cell. Cardiol. 2003, 35, 217-222. [CrossRef]

28. Smith, B.R. Magnetic resonance microscopy in cardiac development. Microsc. Res. Tech. 2001, 52, $323-330$. [CrossRef]

29. Dhenain, M.; Ruffins, S.W.; Jacobs, R.E. Three-dimensional digital mouse atlas using high-resolution MRI. Dev. Biol. 2001, 232, 458-470. [CrossRef]

30. Jacobs, R.E.; Ahrens, E.T.; Dickinson, M.E.; Laidlaw, D. Towards a microMRI atlas of mouse development. Comput. Med. Imaging Graph. 1999, 23, 15-24. [CrossRef]

31. Sharpe, J.; Ahlgren, U.; Perry, P.; Hill, B.; Ross, A.; Hecksher-Sorensen, J.; Baldock, R.; Davidson, D. Optical projection tomography as a tool for 3D microscopy and gene expression studies. Science 2002, 296, 541-545. [CrossRef] [PubMed]

32. Sharpe, J. Optical projection tomography as a new tool for studying embryo anatomy. J. Anat. 2003, 202, 175-181. [CrossRef]

33. Lickert, H.; Takeuchi, J.K.; Von Both, I.; Walls, J.R.; McAuliffe, F.; Adamson, S.L.; Henkelman, R.M.; Wrana, J.L.; Rossant, J.; Bruneau, B.G. Baf60c is essential for function of BAF chromatin remodelling complexes in heart development. Nature 2004, 432, 107-112. [CrossRef]

34. Colas, J.F.; Sharpe, J. Live optical projection tomography. Organogenesis 2009, 5, 211-216. [CrossRef]

35. Breckenridge, R.; Kotecha, S.; Towers, N.; Bennett, M.; Mohun, T. Pan-myocardial expression of Cre recombinase throughout mouse development. Genesis 2007, 45, 135-144. [CrossRef] [PubMed]

36. Jeansson, M.; Gawlik, A.; Anderson, G.; Li, C.; Kerjaschki, D.; Henkelman, M.; Quaggin, S.E. Angiopoietin-1 is essential in mouse vasculature during development and in response to injury. J. Clin. Investig. 2011, 121, 2278-2289. [CrossRef] [PubMed]

37. Anderson, G.A.; Wong, M.D.; Yang, J.; Henkelman, R.M. 3D imaging, registration, and analysis of the early mouse embryonic vasculature. Dev. Dyn. 2013, 242, 527-538. [CrossRef] [PubMed] 
38. Wang, S.; Garcia, M.D.; Lopez, A.L.; Overbeek, P.A.; Larin, K.V.; Larina, I.V. Dynamic imaging and quantitative analysis of cranial neural tube closure in the mouse embryo using optical coherence tomography. Biomed. Opt. Express 2017, 8, 407-419. [CrossRef]

39. Singh, M.; Raghunathan, R.; Piazza, V.; Davis-Loiacono, A.M.; Cable, A.; Vedakkan, T.J.; Janecek, T.; Frazier, M.V.; Nair, A.; Wu, C.; et al. Applicability, usability, and limitations of murine embryonic imaging with optical coherence tomography and optical projection tomography. Biomed. Opt. Express 2016, 7, 2295-2310. [CrossRef]

40. Liu, M.; Maurer, B.; Hermann, B.; Zabihian, B.; Sandrian, M.G.; Unterhuber, A.; Baumann, B.; Zhang, E.Z.; Beard, P.C.; Weninger, W.J.; et al. Dual modality optical coherence and whole-body photoacoustic tomography imaging of chick embryos in multiple development stages. Biomed. Opt. Express 2014, 5, 3150-3159. [CrossRef]

41. Raghunathan, R.; Singh, M.; Dickinson, M.E.; Larin, K.V. Optical coherence tomography for embryonic imaging: a review. J. Biomed. Opt. 2016, 21, 50902. [CrossRef] [PubMed]

42. Chen, Q.; Jin, T.; Qi, W.; Mo, X.; Xi, L. Label-free photoacoustic imaging of the cardio-cerebrovascular development in the embryonic zebrafish. Biomed. Opt. Express 2017, 8, 2359-2367. [CrossRef] [PubMed]

43. Ewald, A.J.; McBride, H.; Reddington, M.; Fraser, S.E.; Kerschmann, R. Surface imaging microscopy, an automated method for visualizing whole embryo samples in three dimensions at high resolution. Dev. Dyn. 2002, 225, 369-375. [CrossRef] [PubMed]

44. Sivaguru, M.; Fried, G.A.; Miller, C.A.; Fouke, B.W. Multimodal optical microscopy methods reveal polyp tissue morphology and structure in Caribbean reef building corals. J. Vis. Exp. 2014, e51824. [CrossRef] [PubMed]

45. Srinivasan, S.; Baldwin, H.S.; Aristizabal, O.; Kwee, L.; Labow, M.; Artman, M.; Turnbull, D.H. Noninvasive, in utero imaging of mouse embryonic heart development with 40-MHz echocardiography. Circulation 1998, 98, 912-918. [CrossRef]

46. Phoon, C.K.; Ji, R.P.; Aristizabal, O.; Worrad, D.M.; Zhou, B.; Baldwin, H.S.; Turnbull, D.H. Embryonic heart failure in NFATc1-/- mice: Novel mechanistic insights from in utero ultrasound biomicroscopy. Circ. Res. 2004, 95, 92-99. [CrossRef] [PubMed]

47. Kulandavelu, S.; Qu, D.; Sunn, N.; Mu, J.; Rennie, M.Y.; Whiteley, K.J.; Walls, J.R.; Bock, N.A.; Sun, J.C.; Covelli, A.; et al. Embryonic and neonatal phenotyping of genetically engineered mice. Ilar. J. 2006, 47, 103-117. [CrossRef]

48. Phoon, C.K. Imaging tools for the developmental biologist: Ultrasound biomicroscopy of mouse embryonic development. Pediatr. Res. 2006, 60, 14-21. [CrossRef]

49. Golden, H.B.; Sunder, S.; Liu, Y.; Peng, X.; Dostal, D.E. In utero assessment of cardiovascular function in the embryonic mouse heart using high-resolution ultrasound biomicroscopy. In Cardiovascular Development; Humana Press: Totowa, NJ, USA, 2012; pp. 245-263.

50. Weninger, W.J.; Meng, S.; Streicher, J.; Müller, G.B. A new episcopic method for rapid 3-D reconstruction: applications in anatomy and embryology. Anat. Embryol. 1998, 197, 341-348. [CrossRef]

51. Weninger, W.J.; Mohun, T. Phenotyping transgenic embryos: A rapid 3-D screening method based on episcopic fluorescence image capturing. Nat. Genet. 2002, 30, 59-65. [CrossRef]

52. Weninger, W.J.; Floro, K.L.; Bennett, M.B.; Withington, S.L.; Preis, J.I.; Barbera, J.P.; Mohun, T.J.; Dunwoodie, S.L. Cited2 is required both for heart morphogenesis and establishment of the left-right axis in mouse development. Development 2005, 132, 1337-1348. [CrossRef] [PubMed]

53. Weninger, W.J.; Geyer, S.H.; Mohun, T.J.; Rasskin-Gutman, D.; Matsui, T.; Ribeiro, I.; Costa Lda, F.; Izpisua-Belmonte, J.C.; Müller, G.B. High-resolution episcopic microscopy: A rapid technique for high detailed 3D analysis of gene activity in the context of tissue architecture and morphology. Anat. Embryol. 2006, 211, 213-221. [CrossRef] [PubMed]

54. Geyer, S.H.; Mohun, T.J.; Weninger, W.J. Visualizing vertebrate embryos with episcopic 3D imaging techniques. Sci. World J. 2009, 9, 1423-1437. [CrossRef] [PubMed]

55. Mohun, T.J.; Weninger, W.J. Imaging heart development using high-resolution episcopic microscopy. Curr. Opin. Genet. Dev. 2011, 21, 573-578. [CrossRef] [PubMed]

56. Geyer, S.H.; Maurer-Gesek, B.; Reissig, L.F.; Weninger, W.J. High-resolution Episcopic Microscopy (HREM)—Simple and Robust Protocols for Processing and Visualizing Organic Materials. J. Vis. Exp. 2017. [CrossRef] [PubMed] 
57. Denk, W.; Horstmann, H. Serial block-face scanning electron microscopy to reconstruct three-dimensional tissue nanostructure. PLoS Biol. 2004, 2, e329. [CrossRef] [PubMed]

58. Kalson, N.S.; Holmes, D.F.; Herchenhan, A.; Lu, Y.; Starborg, T.; Kadler, K.E. Slow stretching that mimics embryonic growth rate stimulates structural and mechanical development of tendon-like tissue in vitro. Dev. Dyn. 2011, 240, 2520-2528. [CrossRef]

59. Smith, D.; Starborg, T. Serial block face scanning electron microscopy in cell biology: Applications and technology. Tissue cell 2018. [CrossRef]

60. Weninger, W.J.; Maurer, B.; Zendron, B.; Dorfmeister, K.; Geyer, S.H. Measurements of the diameters of the great arteries and semi-lunar valves of chick and mouse embryos. J. Microsc. 2009, 234, 173-190. [CrossRef]

61. Geyer, S.H.; Maurer, B.; Pötz, L.; Singh, J.; Weninger, W.J. High-Resolution Episcopic Microscopy Data-Based Measurements of the Arteries of Mouse Embryos: Evaluation of Significance and Reproducibility under Routine Conditions. Cells Tissues Organs 2012, 195, 524-534. [CrossRef]

62. Geyer, S.H.; Weninger, W.J. Some Mice Feature 5th Pharyngeal Arch Arteries and Double-Lumen Aortic Arch Malformations. Cells Tissues Organs 2012, 196, 90-98. [CrossRef] [PubMed]

63. Geyer, S.H.; Weninger, W.J. Metric characterization of the aortic arch of early mouse fetuses and of a fetus featuring a double lumen aortic arch malformation. Ann. Anat. 2013, 195, 175-182. [CrossRef] [PubMed]

64. Bruneel, B.; Matha, M.; Paesen, R.; Ameloot, M.; Weninger, W.J.; Huysseune, A. Imaging the zebrafish dentition: from traditional approaches to emerging technologies. Zebrafish 2015, 12, 1-10. [CrossRef] [PubMed]

65. Pokhrel, N.; Cohen, E.B.; Genin, O.; Ruzal, M.; Sela-Donenfeld, D.; Cinnamon, Y. Effects of storage conditions on hatchability, embryonic survival and cytoarchitectural properties in broiler from young and old flocks. Poult. Sci. 2018, 97, 1429-1440. [CrossRef] [PubMed]

66. Perez-Garcia, V.; Fineberg, E.; Wilson, R.; Murray, A.; Mazzeo, C.I.; Tudor, C.; Sienerth, A.; White, J.K.; Tuck, E.; Ryder, E.J.; et al. Placentation defects are highly prevalent in embryonic lethal mouse mutants. Nature 2018, 555, 463-468. [CrossRef] [PubMed]

67. Aiello, V.D.; Spicer, D.E.; Anderson, R.H.; Brown, N.A.; Mohun, T.J. The independence of the infundibular building blocks in the setting of double-outlet right ventricle. Cardiol. Young 2017, 27, 825-836. [CrossRef] [PubMed]

68. Lana-Elola, E.; Watson-Scales, S.; Slender, A.; Gibbins, D.; Martineau, A.; Douglas, C.; Mohun, T.; Fisher, E.M.; Tybulewicz, V. Genetic dissection of Down syndrome-associated congenital heart defects using a new mouse mapping panel. Elife 2016, 5. [CrossRef] [PubMed]

69. Spicer, D.E.; Henderson, D.J.; Chaudhry, B.; Mohun, T.J.; Anderson, R.H. The anatomy and development of normal and abnormal coronary arteries. Cardiol. Young 2015, 25, 1493-1503. [CrossRef] [PubMed]

70. Anderson, R.H.; Mohun, T.J.; Brown, N.A. Clarifying the morphology of the ostium primum defect. J. Anat. 2015, 226, 244-257. [CrossRef]

71. Mohun, T.; Adams, D.J.; Baldock, R.; Bhattacharya, S.; Copp, A.J.; Hemberger, M.; Houart, C.; Hurles, M.E.; Robertson, E.; Smith, J.C.; et al. Deciphering the Mechanisms of Developmental Disorders (DMDD): A new programme for phenotyping embryonic lethal mice. Dis Model. Mech. 2013, 6, 562-566. [CrossRef]

72. Weninger, W.J.; Geyer, S.H.; Martineau, A.; Galli, A.; Adams, D.J.; Wilson, R.; Mohun, T.J. Phenotyping structural abnormalities in mouse embryos using high-resolution episcopic microscopy. Dis Model. Mech. 2014, 7, 1143-1152. [CrossRef] [PubMed]

73. Wilson, R.; McGuire, C.; Mohun, T.; Adams, D.; Baldock, R.; Bhattacharya, S.; Collins, J.; Fineberg, E.; Firminger, L.; Galli, A.; et al. Deciphering the mechanisms of developmental disorders: Phenotype analysis of embryos from mutant mouse lines. Nucleic Acids Research 2016, 44, D855-D861. [CrossRef] [PubMed]

74. Wilson, R.; Geyer, S.H.; Reissig, L.; Rose, J.; Szumska, D.; Hardman, E.; Prin, F.; McGuire, C.; Ramirez-Solis, R.; White, J.; et al. Highly variable penetrance of abnormal phenotypes in embryonic lethal knockout mice. Wellcome. Open Res. 2016, 1, 1. [CrossRef] [PubMed]

75. Mohun, T.J.; Weninger, W.J. Embedding Embryos for High-Resolution Episcopic Microscopy (HREM). Cold Spring Harb. Protoc. 2012, 2012, 678-680. [CrossRef] [PubMed]

76. Geyer, S.H.; Nöhammer, M.M.; Mathä, M.; Reissig, L.; Tinhofer, I.E.; Weninger, W.J. High-Resolution Episcopic Microscopy (HREM): A Tool for Visualizing Skin Biopsies. Microsc. Microanal. 2014, 20, 1356-1364. [CrossRef] [PubMed] 
77. Geyer, S.H.; Mohun, T.J.; Kamolz, L.P.; Weninger, W.J. High resolution episcopic microscopy - current applications. Curr. Biotech. 2012, 1, 281-286. [CrossRef]

78. Mohun, T.J.; Weninger, W.J. Generation of volume data by episcopic three-dimensional imaging of embryos. Cold Spring Harb. Protoc. 2012, 2012, 681-682. [CrossRef] [PubMed]

79. Geyer, S.H.; Nohammer, M.M.; Tinhofer, I.E.; Weninger, W.J. The dermal arteries of the human thumb pad. J. Anat. 2013, 223, 603-609. [CrossRef] [PubMed]

80. Tinhofer, I.E.; Zaussinger, M.; Geyer, S.H.; Meng, S.; Kamolz, L.P.; Tzou, C.H.; Weninger, W.J. The dermal arteries in the cutaneous angiosome of the descending genicular artery. J. Anat. 2018. [CrossRef]

81. Geyer, S.H.; Tinhofer, I.E.; Lumenta, D.B.; Kamolz, L.P.; Branski, L.; Finnerty, C.C.; Herndon, D.N.; Weninger, W.J. High-resolution episcopic microscopy (HREM): A useful technique for research in wound care. Ann. Anat. 2015, 197, 3-10. [CrossRef]

82. Ertl, J.; Pichlsberger, M.; Tuca, A.-C.; Wurzer, P.; Fuchs, J.; Geyer, S.H.; Maurer-Gesek, B.; Weninger, W.J.; Pfeiffer, D.; Bubalo, V.; et al. Comparative study of regenerative effects of mesenchymal stem cells derived from placental amnion, chorion and umbilical cord on dermal wounds. Placenta 2018, 65, 37-46. [CrossRef]

83. Wiedner, M.; Tinhofer, I.E.; Kamolz, L.P.; Seyedian Moghaddam, A.; Justich, I.; Liegl-Atzwanger, B.; Bubalo, V.; Weninger, W.J.; Lumenta, D.B. Simultaneous dermal matrix and autologous split-thickness skin graft transplantation in a porcine wound model: A three-dimensional histological analysis of revascularization. Wound Repair Regen. 2014, 22, 749-754. [CrossRef] [PubMed]

84. Hamburger, V.; Hamilton, H.L. A series of normal stages in the development of the chick embryo. J. Morph. 1951, 88, 49-92. [CrossRef] [PubMed]

85. Maurer, B.; Geyer, S.H.; Weninger, W.J. A Chick Embryo with a yet Unclassified Type of Cephalothoracopagus Malformation and a Hypothesis for Explaining its Genesis. Anat. Histol. Embryol. 2013, 42, 191-200. [CrossRef] [PubMed]

86. Maurer-Gesek, B. Malformations of the Great Intrathoracic Arteries caused by Hemodynamic Alterations in Chick Embryos. Ph.D. Thesis, Medical University of Vienna, Vienna, Austria, 2016.

87. Bamforth, S.D.; Chaudhry, B.; Bennett, M.; Wilson, R.; Mohun, T.J.; Van Mierop, L.H.; Henderson, D.J.; Anderson, R.H. Clarification of the identity of the mammalian fifth pharyngeal arch artery. Clin. Anat. 2013, 26, 173-182. [CrossRef] [PubMed]

88. Anderson, R.H.; Brown, N.A.; Mohun, T.J. Insights regarding the normal and abnormal formation of the atrial and ventricular septal structures. Clin. Anat. 2016, 29, 290-304. [CrossRef] [PubMed]

89. Paun, B.; Bijnens, B.; Cook, A.C.; Mohun, T.J.; Butakoff, C. Quantification of the detailed cardiac left ventricular trabecular morphogenesis in the mouse embryo. Med. Image Anal. 2018, 49, 89-104. [CrossRef]

90. Le Garrec, J.F.; Dominguez, J.N.; Desgrange, A.; Ivanovitch, K.D.; Raphael, E.; Bangham, J.A.; Torres, M.; Coen, E.; Mohun, T.J.; Meilhac, S.M. A predictive model of asymmetric morphogenesis from 3D reconstructions of mouse heart looping dynamics. Elife 2017, 6. [CrossRef]

91. Dunlevy, L.; Bennett, M.; Slender, A.; Lana-Elola, E.; Tybulewicz, V.L.; Fisher, E.M.; Mohun, T. Down's syndrome-like cardiac developmental defects in embryos of the transchromosomic Tc1 mouse. Cardiovasc. Res. 2010, 88, 287-295. [CrossRef]

92. Captur, G.; Wilson, R.; Bennett, M.F.; Luxan, G.; Nasis, A.; de la Pompa, J.L.; Moon, J.C.; Mohun, T.J. Morphogenesis of myocardial trabeculae in the mouse embryo. J. Anat. 2016, 229, 314-325. [CrossRef]

93. Geyer, S.H.; Reissig, L.F.; Husemann, M.; Hofle, C.; Wilson, R.; Prin, F.; Szumska, D.; Galli, A.; Adams, D.J.; White, J.; et al. Morphology, topology and dimensions of the heart and arteries of genetically normal and mutant mouse embryos at stages S21-S23. J. Anat. 2017, 231, 600-614. [CrossRef] [PubMed]

(C) 2018 by the authors. Licensee MDPI, Basel, Switzerland. This article is an open access article distributed under the terms and conditions of the Creative Commons Attribution (CC BY) license (http://creativecommons.org/licenses/by/4.0/). 